\title{
In the memories of Wolfram - a Portuguese-Galician Sociolect
}

\author{
Maria Otília Pereira Lage* \\ Researcher CITCEM - FLUP, Portugal
}

*Corresponding Author: Maria Otilia Pereira Lage, Researcher CITCEM - FLUP, Portugal

\begin{abstract}
The tungsten mines dispersed in the western westernmost province of Stanotungstifera are located in hills and valleys of the most remote areas, but always in rural areas. Its exploration, since the beginning of the 20th century, but with redoubled intensity, during the Second World War, corresponded to a very strong movement of technologization of rural spaces, largely still subject to the cyclical rhythm of the seasons, translating, therefore, in a violent and accelerated human interference in nature. It was a whole "mental landscape". That is why talking about mines, whether entering, in what is in mining slang, iscalled "a world apart". We approach that underground mining work, through language, "sound material of a social and historical nature...", 'common collective heritage' of that world apart: "technological environment" "social terrain" and "Ideological map", which we propose to approach through the identification and contextualized inventory of elements of a Luso-Galician sociolect.
\end{abstract}

Key words: Wolfram; Mining world; Literature; Portugal and Galicia, 20th century.

* Note: This is the original english version of my article "Nas memórias do Volfrâmio um sociolecto luso-galaico" VEREDAS 4 (Porto, 2001) 275-294.

\section{INTRODUCTION}

The underground environment is technological - but it is also a mental landscape, a social terrain, and an ideological map."

The underground world of mines whose basic conditions of "habitability" - air and light -are ensured by human action through technical resources, mobilized for this purpose, and an "environment" built from the start, artificial and markedly "technologized".

The wolfram mines spread on stanotungstiferous ${ }^{2}$ province, from the far western Europeare located in hills and valleys of the most recondite places ${ }^{3}$ but always in rural areas. Its exploitation, since the beginning of the century, but with increased intensity, on the occasion of World War II, has corresponded to a very strong movement of technologization of rural spaces, mainly, still submitted to the cyclical rhythm of the stations,converting, therefore, into a violent and accelerated human interference in nature. From this action and the revolving of land, in many cases unused for culture for years, which had an equally or even more powerful effect at the level of all those who participated in it, deep marks in the social and cultural field have remained.

It was a whole "mental landscape" that changed, decisively. So much that, in the case of wolfram and, with particular incidence in the 1940s, thousands and thousands of men and women had so far been dedicated to fieldwork who had access to an environment that foreshadowed in almost everything the new way of city life.An ambiance in which the marked succession of nights and days loses meaning in the continuum of artificial light.

That is why talking about mines, whether entering, in a slang speech, is called "a world apart", where after being there, the most problematic is to get out of it ${ }^{4}$.That is why, talking about wolfram, it's to talk about intensive mining cyclically guided by the wars that mostly have defined our century ${ }^{5}$. In short, it's a world, in many ways, underground.

"Ideologically", that world and the magnetic attraction it has exercised over time, over humanity integrates a structuring principle of its own spatial organization along a vertical axis, which belongs to the sky, overloaded with promises of salvation, the upper level, and the treacherous place of mud, sludge and noise of the mechanized nature,"technologized place", hell of all punishments, the lower level, to the human life, remaining the condition of divided passenger between an unforeseen 
departure and an always early arrival of an irreparably short trip. This view of the world and the position occupied by man, shaped, in the west, the culture of peoples largely supported by awhole historiography and literary creation, having as a paradigm or closest reference the already classic coal mining, infrastructure of the industrial revolution, a phenomenon considered the inauguration of industrial capitalism. ${ }^{6}$ But its roots are lost in the night of time. There is a whole dark story of descent into hell to the spectral world of the dead, on which beliefs, myths and narratives are composed with a common background, and which, even today, jumps us on the road, in the moments of greatest distress, with the strength of the things that made us the possibility of being.

This view of the world is a mandatory crossing point when we want to approach this underground mining work, when we have to penetrate through the language "sound material of a social and historical nature by excellence...common collective heritage" ${ }^{7}$, in this part-world, "social terrain" that we have been studying in its multimodal manifestations, and that here, we propose to develop through the identification and contextualized inventory of elements of a Luso-Galician sociolect of the social groups in which they are based. We do this with regards to the passage and subsequent adoption of a word with a strange sonority - wolfram - ${ }^{8}$ the volfro and wolfram of thousands of Portuguese and Galicians ${ }^{9}$ who gave themselves, by task and own account on the "mineral seek" or employees that surrendered, on the underground lodes of mining exploitations registered by concessions and national or foreign companies - Borralha, Santa Comba, Panasqueira, la Silleda, Vale das Gatas, Monte Neme, Arteixo, Adoria, and so many others deposits and mines the most rich in the world in wolfram - ${ }^{10}$ metal separated in laboratory just 200 years ago, and brought by its several industrial capabilities to the category of strategic metals, being considered the metal of the 20th century.

In Portugal but also in neighboring Galicia, the rush to the wolfram with its intense demand by the two belligerent blocs of World War II, it was a central episode in the lives of the populations, largely emigrated in the post-war period. Historical movement enshrined in the designations "issue of wolfram", "wolfram's war", "long saga of wolfram's battle", and as for us the institute of modernity, shadowed by in historiographical and sociological practices, we have been studying it, while a "frontier object" for a historical sociology of contemporary Portugal. In this context, we see it here as the nucleus that organizes a constellation of sociolinguistic expressions, that make up the dialect of social groups of that "world-apart", the underground mining world. Just then, "Volfro", "wolfram", "volfrão", "ouro negro"(black gold), "china", "volframistas", and other terms of similar rooting, are the expression of the same babbling "language", in its several variants, smuggling at the frontier and with emigration, from the same space - sociocultural time where several logics or social worlds are mixed constituting themselves in the worldview which understanding, the study of the Portuguese society (1930-1960) acquires a new line of investigation. The discussion of this argument of anonymous social history that combines what we designate "in the memories of the wolfram", a Portuguese-Galician sociolect12 is done, trying to take as a theoretical resource the sociological notion of "articulated testimonies" 13 , of a new critical theory, through the interpellation of memories and testimonials and the interrogation of materials that are part of the "fictional world" of fictions and "social intervention" novels, who took the miners saga and the subject of the wolfram for literary matter

\section{The Social Ground}

In Portugal, and in the identical process, in Galicia,took place socially around the words 'volframio', wolfram and 'destaxistavolframistas' elements of a lusogalician sociolect and an intense and mixed philonian constellation of worlds mental landscapes, and ideological maps, that certain literature of the time was echoed. With these and other materials - speeches, autobiographical narratives, oral and visual history records - we try to work on social memories to reconstruct, insofar as they will have manifested and for that contributed a deep and slow social and cultural change, politically obscured, and whose understanding, challenges other excavations of old and new veins of our contemporaneity, in an analysis perspective that integrating the "contemporaneity of tomorrow of those who haven't yesterday or today "14, that favors the study of practices and representations, and the means of technology and science then in affirmation.

The wolfram, "the same" of that German Wolfram, English and Galician ${ }^{15}$ enters in the Portuguese languagegiving name to a rare and valuable metallic mineral for the modern industry.But beyond its more precise meaning, the wolfram - the "volfro", "volfrão", "volfram" and "ouropreto" (black gold) of the populations, so many other elements of the sociolect that we made inventory - would become, 
by the exorbitant prices it reached, in terms of comparing all or almost all products that, by induction, , reached speculative prices, still almost inconceivable today, from olive oil to potatoes, and to the bread itself whose faminewasthenmeant"worsethanwolfram".

The characteristics of their exploitation led to subsequent changes in the ways of life and customs of the populations who, without work or abandoning traditional and less profitable activities, gave themselves over to their extraction and trade, few knowing for sure their final destination, all looking for a thousand arts and tricks to sell at the best prices - going up / down in the game of the crossed networks of intermediaries at the service of one or the other or both belligerent blocks, in businesses maintained by cheap or free money from German-Nazi extortion of gold and Jewish goods and other minorities and for the lives of the people who were victimized in the short space of those years. "The Mine is a relentless flood, which is always and always growing" and people rush to the "harvesting of the mineral", in the open sky -- "there are houses that men throw down so as not to lose the trail of a thread" -, or for extracting the tungsten, in underground work, looking for the "pockets", chasing veins under the ground, smashed into wells and galleries opening to the rails and carts, through cross streets like an underground urban plan.

In the social upheaval and chaotic change thus generated, the polychrome design of very rich human frescoes, episodes and faceties of great vivacity, where the "robbers", "those of the kilo", the "one hundred grams", the "pickers", the "contractors", the "catchers" and "washers" abound, according to the uses of the mining regions, picking up, diverting, falsifying and selling ore, and there are the "volframists" everywhere, the "farristas" of Minas da Borralha, in Gerez, the Galician "destaxistas" buying, selling and counterfeiting. New social figures, new images and symbologies in which they are sudden and fabulously reborn,the old sight of the easy wealth of "cartos", "peludas", "kilo banknotes" or "short stories" that filled the wallets and served to immediately access the external signs of wealth wholesale and spine books, fountain pens to display on the lapel pocket, raincoats to put on the arm, "twice foam" mattresses, better than single-foam, riding a horse on trips to city pleasures and business, in rented cars and taxis that were starting and becoming common as a way of public transport. New riches and excesses of all kinds in the trade of the "business of china", whose fabulous sums moved, have probably allowed to a few to accumulate hidden fortunes, new traders to solve their lives and improve the one of their children, through studies - a new generationthe one of the "wolfram's sons" - to many others having left them as poor as before, thus justifying the old aphorism that water gave it water took it. Nothingleaving, as before. ${ }^{16}$

Our time has already been called, due to the fact that the phenomenon marked the middle, wolfram time. I want to believe there is an exaggeration on the expression. Among us, such furunculosis, with its dramatic nature, must first of all touch one of the eruptive manifestations of the social crisis that the world is going through. Wolfram here, oil beyond, rubber there, we must integrate them in the complex and fearful substrate that engendered the war. ${ }^{17}$ In the "battle of the wolfram", a time of smuggling and "candongas", these images of "fingers stuffed with rings, suits of the city master, telling adventures with wide eyes" ${ }^{18}$ and bourgeois miners ${ }^{19}$ melting the gains to buy cheetah for silk, they run alongside another world that the "volfro" has not bewildered, of thousands of workers and miners,ex-farmers and daily workers, dying young with "the evil of the dust" or "cramped" of the "tuff",crippled in the frequent disasters due to the desire for gain and lack of care, wedged between pensions of poverty and insurance denies, eating in the mine "bread and knife". Little visible worldlikeothers, mobilizersoftechnocultures and imported terminologies, which highlighting technical and formalized ${ }^{20}$ knowledge would be reappropriated, object of miscegenation with lay practices and knowledge.A whole social territory where different worlds and contrasting logics, are put in relation to each other.

\section{The Socio-Technical EnVironment: The Paleotechnic OF Industry.}

In the North and Center of Portugal, as in Galicia, were (re)activated, on the context of World War II, thousands of small, medium size and large mines that, basically using mining machinery and technology imported from the countries of the center of capitalism (England, Germany, France, etc.) ${ }^{21}$ started to absorb the labor then widely available. This fact is an evident testimony to the exploitationof the apprehensible wolfram at the level of the emergence of the Portuguese-Galician sociolect whose inventory continues. Most of the country's many small and medium-sized mines, under intense German exploitation, it was theGerman language from which wolfram derives "volframio" (portuguese expression), and perhaps, the much desired "chinas"22 - black stones, very 
mineralized -, still today effusively remembered all over the world where have emigrated those who were looking for them before. (In other places, such as Couto Mineiro da Borralha, for more than 50 years, operated by French capital,was for example the case of the French vocabulary poches, followed by others, while at Panasqueira mines, exploited by british people,since the 1930 decade, the same has occurred with the English language), being all of them, by diverse ways of reception,smuggled and linguistic trade, in a process of profound mixture of "lay" and "experts" knowledge in socioprofessional contexts.

"Here at Panasqueira, the first disassembly method was... oh Zé Duarte, how is it?... The oldest was "lace and embroidery "... it was what was done during the war and continued until 50 and such ... from 1937 to 1948 it was just that... the "cod" or "fan"... no, long wall is something else is the "parallel fronts" and it was until around 1980 ... the cod or fan was used until 1977/1978...it was with hammers to save energy... We were progressing on the rock... and the blistering that was left remain there, we made the barriers... and mud embankments to build walls... so the gunpowder fire doesn't burst with the walls... this is how the fan is made... then we move on to the parallel fronts... and since 1960-70, the method that is now used, the "chambers and pillars" method... the " spine "... here you can see better in this set of drawings... we made streets and screwed them... rolfbotes... on the "pêlos" (bristles)... are cracks... where the rock breaks...we putted an iron with a crack in one part and a wedge at the end sothat to hold the ground... get more stuck... so we put the "pampeso"... it was such a half inch iron... to hold the bottom stones with the top stones... you still can see outside... that was so called "drillng against God"... but it didn't work ... the bottom stone broked and the iron remained there alone and the stones were spoiled... it spoiled even more... that's why it was called drilling against God... do you know what the spaces between gallery barriers are called?... "ears"... On mining, there is also the construction of chimneys ... the royal chimney and the twin chimney... the royal one is made for the product to exit and the twin one is for the people to come out... there were also several construction processes... first they were made with wooden rollers... stairs and landings... later came the cage method ... several individuals died in these jobs... ... and say that an individual who is at risk earns less than another who is safely in the office or cabinet..."23

Geology was also profoundly reinvented in terms of sociolect, where many of the terms appear associated with the life of the rural world, but also, curious and distantly, From the "eel tail", where the vein suddenly ends, a lenthicle that indicates the existence of lenthicular veins, arousing the greed of the miner to follow him, from the silica impregnation of the rock to the "galo" (cock) name that mining people call "ligal" (small lode that connects two lenthicles in a row); sometimes finding a "risqueiro" (scratch), that brings you closer to the main lode, more rich sometimes the lode "assenta" (settles) and it is easy to explore because it follows horizontally; other times the lode "dives" or "bounces" and it becomes difficult to follow; sometimes the "cock crossed" the vein, the vein appears in the "wild pebble", clay shale impregnated with quartz, non-mineralized, hard and difficult to pierce, or in "ferrenho", (dolerite), also hard rock and difficult to drill, therefore, two great enemies of the miner; ; other times the lode "deunafalha" (touched the fault) that can be "a falhagorda" (the fat fault) that crosses the mine and causes great irregularity in the veins24. In alluvial deposits and old mines, the "rich lode" for the populations, were the mining work, the joy of finding "chinas" (very mineralized stones) in those "bossadinhas" (bouçadas).

The widespread technologization of these rural spaces, their 'rurbanization' - early entry,the abrupt, and marked by the ephemerality of the Portuguese rural world, in an ad hoc urbanization process, raised by the characteristics of intensivewolfram exploration, generator of intense and vast population mobilities-, and another characteristic of this technologized world, inducing elements of the sociolect that we made inventory and which in turn is a space for "inscription" of the changing socio-technical environment that has also been outlined.

\section{IDEOLOGICAL MAP: FROM NAMELESS OBJECT TO LITERARY OBJECT - THE WOLFRAM.}

\subsection{Aspects (Modes) - Inscription of Mining Worlds in Literary Fiction.}

The wolfram is leitmotiv of the literary textual corpus whose production follows a period that, throughout the first half of our century, goes from the beginning to the phase of its most intense exploration, and thatnthe imaginary is constituted. It is composed of: the cordel novel "Autobiography of Borralha", from the beginning of the century, in which this mineral does not yet have a proper name; The novel "Volframio", published in 1942, which under a point of view centered on the 
intricacies of German exploitation, which in fact gives it its name, dramatizes its national exteriority; The 1944 novel "Mineiros", which opposes the mine's gear to an ideal mining center project; The 1946 novel "As Minas de S. Francisco" that follows the metamorphosis of the old rural world into the strange new world of mines; the autobiographical soap opera "Era Tempo de Apandar"(It was time for Swelling), which on the other side of the border, in the narrative of the "estraperlo" (illegal trade promoted by companies) of the wolfram, ${ }^{25}$ mirrors the smuggling of Portuguese wolfram; The Galician short story "O Marelo (Apocalypse Now)", a short literary note of ancient biblical prophecies summoned by evil and the violence of powers.

Projected in the subsequent times of the hydroelectric projects "O Lodo e as Estrelas" (The Slime and the Stars) retained in the memories of many of the protagonists of the "saga of wolfram", articulates in poems the transition from the work suffered in the galleries of the mines to the work in the tunnels of the barriers.

Just because it was structured in this way, the fictional corpus presented allows us to draw a reading frame. If in the autobiography in verse by Borralha, pastor and miner, ${ }^{26}$ we have the mythical narrative of the origin (of the unnamed mineral), poured into a mold of tragedy, "Volfrâmio", "Minas de S. Francisco" and "Mineiros" draw, in the different modes and aspects of the action that takes place around the mining of volfro=wolfram, human and non-human beings that are worth by themselves and exceed everything lived, in different configurations of perceptives - not perceptions, because independent of the state of those who experience them - and affections - which are no longer feelings or tenderness, exceed the strength of those who pass through affections. ${ }^{27}$

The border line with the outer side of this frame being marked, as has been said, for "Era tempo de Apandar" (It was time for Swelling), autobiography of a political prisoner forced to work hard in Galicia's tungsten mines. Overflowing this structure, as its escape line, the small collection of short poetic texts "O Lodo e as Estrelas"(0 Slime and the Stars), elected mines and dams workers.

This symbolic corpus does not measure on a large scale this absent the sociolect, however, it takes root in a collective imagination of a nocturnal history in which the recurrence of the dualistic canon heaven/hell, gods/demons, good/evil, reason/unreason, doom/salvation - it is updated, in expenditure, waste and excess, in the (ir)reversible ${ }^{28}$ line of events and contexts, arrow and cycle of time.According to this imaginary, the infernal vision of underground work, confirmed in the numerous deaths of young miners that refreshes the social imaginary of the"Quatrocavaleiros do apocalipse" (Four horsemen of the apocalypse) - hunger, misery, plague and war - the monsters of the " Torre de Madorna "(Madorna's Tower) that eat little children, the venomous and hideous beings of darkness against which the clear dream of a city of utopia contrasts, a phalanx of social harmony. Imaginary that develops in the long continuity of a tradition of the entire caste of powers and empires, that is lost in the memory of the times, financial groups and large mining companies that strategically, has checked almost all mineral resources on the planet.

\section{The mental landscape}

The reception of the strange word and the translation that the populations of Portugal and Galicia made of it, making it enter in a daily life that has changed profoundly- movement of city life attraction, self-employment, intensification of business means, public works, new consumption habits and behaviors, upheaval of the traditional agrarian world and slow and stifling displacement ${ }^{27}$, but irreversible from its predominance to the increase of other activities, namely manufacturing, the generalization of the entry of women in the labor market, the reemergence of emigration waves, etc., and whose change the thing named was the trigger, it is clear to us in the context of "situated knowledge", the intersection of different social memories that (re)configure nomadic and sedentary practices, lay knowledge and experts.

"Lembro de trabalhar na busca do volfrâmio na época da guerra numa companhia alemã num lugar chamado Pranheira... Carrazeda de Ansiães... Então fui para lá lavar daquela terra que saía dos tuneles onde saía o minério ....andei muito tempo eu e muito pessoal a lavar aquela terra... onde ficava o volfrâmio no fundo daquelas caleiras de madeira... Essa companhia saiu mais ou menos em 1946, 1947 mas depois ficaram uns portugueses lá com ela... ficaram uns 3 a 4 anos... mas já era uma exploração mais fraca... o volfrâmio trouxe bastante benefício porque acontece o seguinte trabalhava lá muita gente daquelas aldeias todas por ali e de outras terras... então muitos começaram a explorar aqueles terrenos por conta deles e a vender para compradores... mas aquilo era uma coisa provisória 
faz de conta que era como estes mineiros aí em Minas que andam atrás do ouro... garimpeiros... assim era na altura la em Portugal..."29

("I remember working on the search for wolfram at the time of the war in a German company in a place called Pranheira ... Carrazeda de Ansiães ... So I went there to wash that earth that came out of the tunnels where the ore came out ... I walked a long time and a lot of people washing that land... where the wolfram was at the bottom of those wooden gutters ... That company left more or less in 1946, 1947 but then some Portuguese stayed there with it ... they stayed for about 3 to 4 years ... but it was already a weaker exploration ... The wolfram brought a lot of benefit because the following happens ... a lot of people worked there from all those villages over there and from other places... so many started to explore that land on their own and sell it to buyers ... but that was a temporary thing, pretending that it was like these miners there in Minas who are searching for gold... prospectors ... it was like that at the time in Portugal ... ") $)^{29}$

The following narrative is composed of identical materials, where incorporating corresponding elements of the sociolect, is drawn, for neighboring Galicia, at the time of "Fevre do wolfram"30 (Wolfram fever), "Tempos de Apandar" (It was time for Swelling), a physical environment and a mental landscape equivalent to that previously described and occurred in the regions of the North and Center of Portugal.

"[...]as minas já fecharam há uns anos... trabalhei aqui quando tinha 18 anos por esta finca abaixo e arriba... estava cheio de caleiras... havia aqui unas casetas ondetínhamos as cousas... trabalhava como labadero... a céu aberto... primeiro esteve a Companhia FérreaMineria... depoislebou-a um chamado Mariano...depois de Mariano um cristano de S.Roque... e outro do Carballo... e dois que morreram... a general de riba lebaba-aXinto... morreram todos... um tal Eglesias que bibe na Coruña... éoúnico que ficou ${ }^{31}$ e mais o Soeiro de Carballo... esse era o dono de una casa de seguros mui importante em Carballo... eun de una casa grande na beira da carretera que bai a Malpica tambienestibera aqui com lavaderos e lavaderas ó volfrão... o de Monte Neme era muito melhor que de Verilongo... trabalhei aqui no volfrão cinco anos ... os Varelas compravam-lhe fora da mina... si. .. si... eram os destaxistas... um fulano de cá... que era aloucado... erao pirata negro... chamavamos-lhe assim ... marchou para Montevidéu... Habia aícaleras de madeira... tinha aqui um poço e lavavamos da parte de cima quando libraram o canal... eu de noite vinha por ele ali... os carros carrejavam o mineral de lá de riba... cobravam-nos pouco por cada carro... $1000 \mathrm{~kg}$ de terra... 15 a 20 pesetas... vou por aí mirando e se vejo uma chininha, se me gusta levo... foram os mais velhos que puseram o nome de china de mineral... há muitos que chamam aos adubos mineral. .. são os abonos dos prados... mas nós chamamos volfram... volfrão... volfram... mineral. .. aqui houve quem acendesse um cigarro com bilhete de 1000 pesetas... dizem... "32

\section{Conclusion: "Articulated testimonies"}

The analysis carried out assumed the exercise of "a constellation of modes of involvement and intervention"33. The articulation work between discourses, narratives, novels and the sociolect emerging from the memories of the wolfram, of which diatopically we try to make interpretation, testifies to the need felt in the course of the research carried out to bring in close but different perspectives of a sociohistorical approach to the process of exploring the wolfram, short but intense, which was facilitated by the fact that they show us in different variants of the same language, according to some, the Galician-Portuguese, or in different but contiguous languages, Galician and Portuguese, according to others. ${ }^{34}$

In the memories of the exploration of a recent metallic mineral - wolfram - the emergence of elements of a sociolect as well as literary compositions are roots of a rhizome inscribed in the corner of a page that of the (mining) wealth of the nations, one of the best kept secrets of their economies. Portugal and Galicia, geologically linked by the same mineralized veins, enclave economies when their own wealth did not serve their self-development, they were also socially and culturally in this unique historical process, in the specific way that we seek to see.

\section{WORKS CITED}

[1] AVILES DE TARAMANCOS, Anton, "Os tempos do wolfram", Cadernos A Nosa Terra, Dossier "Os anos despois (1936-1953)".

[2] BASTOS, Oscar Teixeira, "Uma desobediencia no tempo do volframio", Revista Policia Portuguesa, Saparata (Jul-Ag. 1946). 
[3] BATOQUE, Antonio, "A Quimera do Yolframio e uma falsificar;iio com base $1 \mathrm{~W}$ art ${ }^{\circ} 2520$ do COd. De Proc. Civ.: A margent de uma questiio mineira, Coimbra, Coimbra Ed LdB , 1943.

[4] BENJAMIM, Walter, "Problemas da Sociologia da Linguagem", in Walter Benjamim, Sobre Arte, Tecnica, Linguagem e Politica, Lisboa, Relogio d'Agua, 1992. p. 197-229.

[5] BLOCH, Marc, História e Historiadores: textos reunidos por Etienne Bloch, Lisboa, teorema, 1998.

[6] CABA, Carlos, Wolfram, wolfram!,Ediciones Morata de Arxentina, 1947.

[7] CAMPOS, Jorge de, As minas na toponimia de Portugal (elementos para a sua historic), Lisboa, Ed. de Autor, 1944.

[8] CAPINHA, Graça, "Tecendo e distorcendo o colonialismo da linguagem... A Poesia e Nos" Revista Critica de Ciencias Sociais, 47 (Coimbra, Fev. 1997) p. 65-72.

[9] CAPINHA, Graça, A producao do discurso literario num contexto de globalização: a propósito da dialectica da colonização de Alfredo Bosi, Coimbra, Oficina do Centro de Estudos Sociais, 1995, nO 56.

[10] CAROLA, Carlos Renato, Dos subterrtineos da Hist6ria: as trabalhadoras das minas de carviio de Santa Catarina (1937-1964), Florianopolis, Universidade Federal de Santa Catarina, 1997. CERUTTI, Simona, "Normeset pratiques", in Bernard Le Petit, dir., Les formes de l'experience: une autrehistoiresociale, Paris, Albin Michel, 1995, p. 127-149.

[11] CHARTIER, Roger; PIETRO, Corsi, dir., Scienceet langue enEurope, Paris, EHESS, 1996.

[12] COSTA, Mendes da, Yolframio e estanho....Porto, Domingos Barreira, 1946, 2.\& ed.

[13] DELEUZE, Gilles, 0 fio de Ariana, Lisboa, Ed. Vega, 1996. DERRIDA, Jacques, 0 outro cabo, Coimbra, Reitoria da Universidade, 1995.

[14] DIAS, Jaime Lopes, "Volfrfunio e estanho na vida e costumes da Beira Baixa", Separata da Revista de Etnografia 23 (Porto, Museu de Etnografia e Hist6ria, Junta Distrital do Porto, [s.d.]).

[15] DUCROT, Oswald; TODOROV, Tzvetan, Dictionnaireencyclopediquedessciencesdulangage, Paris, Ed. duSeuil, 1972.

[16] FARINA JAMARDO, Jose, La balada del Wolfram, Editorial MagisterioEspanol, 1977.

[17] FERRAZ, Telmo, 0 lodo e as estrelas, Porto, Ed. Autor, 1960. --, GaliciaToponimia 1/250.000, Xunta de Galicia, Direcci6n General del Instituto Geografico Nacional, 1986.

[18] GUILLEMOT, Helene, "Comment reagir face aux risques technologiques", Science\& V 979 (Paris, Avr.1999) p. 92-97.

[19] KEMLER, John H., Thestruggle for wolfram in theIberianPeninsula (Jun. 1942 - Jun. 1944), Chicago, University of Chicago, 1949.

[20] KROLL, Heinz, 0 eufemismo e 0 disfemismo no portugues moderno, Lisboa, ICALP, 1984. LEAL, Manuel Vaz, As Minas da Panasqueira: vida e história, Lisboa, Portugalia Editora, 1945. LECOURT, Dominique, "Lelangage au tribunal de la science: A proposduCircle de Vienne", in Roger Chartier; CorsiPietro, dir., Scienceet langue enEurope, Paris, EHESS, 1996, p. 203-208. LEVY-LEBLOND, Jean Marc, "La langue tire la science", in Roger Chartier; CorsiPietro, dir., Scienceet langue enEurope, Paris, EHESS, 1996, p. 235-245.

[21] LIMA, Martinez de, W03: a Febre do. volframio (episodio nortenho da grande guerra 1939-1945), Porto, Ed. de Autor, 1953.

[22] LOPES, Oscar, A busca de sentido. Lisboa, Caminho, 1994.

[23] LOURENQO, Eduardo, Sentido e forma da poesia neo-realista, Lisboa, D. Quixote, 1983.

[24] MATA, Eugenia; VALERIO, Nuno, História económica de Portugal: Uma perspectiva global, Lisboa, Presenc;a, 1994.

[25] MOTA, Carlos Guilherme Mota, "Em busca de uma mem6ria comum", Revista Critica de Ciências Sociais 32 (Coimbra, Jun. 1991).

[26] NAMORA, Fernando, Minas de S. Francisco, Lisboa, Ed. Inquerito, 1952, 2\& ed. Refundida. NAMORADO, Joaquim, Uma poetica da cultura, Lisboa, Caminho, 1994.

[27] NAMORADO, Joaquim, "Urn romance visto por dentro ... " in António Pedro Pita, org., Joaquim Namorado : obras, ensaios e criticas: Uma poética da cultura, Lisboa, Caminho, 1994. NASCIMENTO, Manuel do, Mineiros, Porto, Livraria Latina Editora, 1944.

[28] NEIVA, Cotelo, Jazigos de cassiterite e volframite. Porto, Faculdade de Ciencias, Comunicacões dos Serviços Geológicos de Portugal, 1944, tomo XXV.

[29] NUNES, Gilda, Os lavradores do volfrâmio, Montalegre, Camara Municipal, 1995.

[30] NUNES, Joao Arriscado, "Para alem das "duas culturas": tecnociencias, tecnoculturas e teoria critica", Revista Critica de Ciencias Sociais 52-53 (Coimbra, Nov.98-Fev.99) p. 5-50. 
[31] PASLEAU, Suzy, La perception de La vieactive: d'une etapedansleprogres social a la mesure d'unfacteur de production, Seraing (XIX-XX siecles), Universite de Liege, 1997.

[32] PITA, Ant6nio Pedro, 0 poetico e os saberes, Coimbra, Oficina do CES, 1991, n," 28.

[33] PONDAL, Isidro Parga; GARRIGA, Vasquez, "Contribucion al estudio de los minerales de volframio de Galicia. I) Analisis de las volframitas de la Brea, Corpifio y Carboeiro, Lalin (Pontevedra), II) Analisis de la scheelitas de Garcia y Villare de Cervos e Pondal, Isidro Parga e Garriga, Vasquez - Contribución al estudio de los minerales de volframio de Galicia. III) Analisis de volframitas de Juno Monte Neme, Casaio e Vila Cova", Anal. De la Real Soc. Esp. de Fis. y Quim tomo XXVIII (1930) p. 82 e 905.

[34] RAMALHO, Maria Irene, "A Poesia e N6s", Revista Critica de Ciencias Sociais 47 (Coimbra, Fev. 1997) p. 5-21.

[35] RAMON DE VALENZUELA, Era tempo de apandar.6, Jorge do, "Elementos para uma História Social do Salazarismo (1939-1958)", in A. H. de Oliveira Marques, coord., Historia de Portugal Contemporânea: economia e sociedade, Lisboa, Universidade Aberta, 1993.

[36] PEREIRA, Jose Jorge Alvares, Riquezas mineral6gicas de Barroso e sua historia, Montalegre, Ed. da Camara, 1984.

[37] REIS, Daniel; PAUlOURO, Fernando, A Guerra da Mina e os mineiros da Panasqueira, Lisboa, Regra do Jogo, 1979.

[38] REVEL, Jacques, "L'institutionetle social" in Bernard LePetit, Les formes de l'experience, Paris, Albin Michel, 1995.

[39] RIBEIRO, Antonio Sousa, Walter Benjamim, pensador da modernidade, Coimbra, Oficina do CES, $1994, n^{\circ} 41$.

[40] RIBEIRO, Aquilino, Volfrâmio: Romance, Lisboa, Bertrand Editora, 1985.

[41] ROSE, Steven, TheMaking of Memory: frommolecules to mind. Toronto: BantamBooks, 1995. SANTIAGO RODRIGUEZ, X. L., dir, realiz., A Fevre do Wolfram, Edic. Xoan Garcia, 1995 (video VHS, 58).

[42] SANTOS, Boaventura Sousa, "Por uma concepeao multicultural de direitos humanos", Revista Critica de Ciencias Sociais 48 (Coimbra, Jun.97) p. 11-32.

[43] SEIXO, Maria Alzira, A palavra do romance: ensaios de genealogia e analise, Lisboa, Livros Horizonte, 1986.

[44] SERRAO, Joel, "A novelística social na decada de 40 - esboço de problematização", Colóquio Letras 9 (Set. 1972).

[45] SOARES, Freitas, Volframio: 0 'barro da Picareta' juntou-se ao 'Marques da Pa', Porto, Livraria Internacional, 1941.

[46] SOBRAL, Fernando Sousa e Silva; MATIAS, Manuel Joao Senos, Volframio, aspectostecnicoeconomicos, Coimbra, Faculdade de Ciencias e Tecnologia, 1980, p. 1-3; p. 51-52.

[47] STENGERS, Isabelle, Pourenfiniravec la tolerance: Cosmopolitiques VII, Paris, La Decouverte /LesEmpecheurs de penserenrond, 1997.

[48] TELO, António, Portugal na Segunda Guerra, Lisboa, Perspectivas e Realidades, 1987, p. 458-459. TORGAL, Luis Reis, "Salazarismo, fascismo e Europa", Vertice 52 (Jan.-Fev., 1993) p. 41-47. TORRES, Alexandre Pinheiro, "Introduçao muito elementar ao neo-realismoportugues", in Entre a Realidade e a Utopia: 0 Neo-realismoliterarioportugues: Catalogo e Roteiro da Exposição", Matosinhos, Camara Municipal, 1996, p. 15.

[49] TORRES FEIJÓ, Elias Jose, "Cultura portuguesa e legitimacão do sistema galeguista: historiadores e fil6logos (1880-1891)", Ler Historia 36 (Lisboa, 1999) p. 273-318.

[50] VILAR, Antonio, 0 Volframio de Arouca: No contexto da segunda Guerra Mundial (1939-1945), Arouca, Camara Municipal, 1998.

[51] VILELA, Mario, "Linguagem e Ideologia", Alma Nacional: Revista Republicana, Livraria Civilização, 1977.

[52] WHEELER, Douglas L., "Theprice of Neutrality: Portugal, theWolframQuestion, andWorldWar II", LusoBrazilianReview XXIII, 1 (1986).

[53] WILLIAMS, Rosalind, Notes onthe Underground: anessayontechonology, society, andtheimagination, Cambridge, Massachusetts Institute, 1996.

[54] "Wolfram, 0 ouro dos anos 40" (reportagem), A Nosa Terra 791 (Ago. 1997) p. 2-3.

[55] ZOLA, Emilio, Germinal, Lisboa, Europa América, [s.d.]

\section{CONSULTED WORKS}

${ }^{1}$ Rosalind Williams, Notes on the Underground: an essay on technology, society, and the imagination, Cambridge, Massachusetts Institute, 1996 , p.21. 
2 The main metallogenic provinces can be defined as: "Sinomalean province; North American mountain range province; Andean province; Australian prov.; prov. of Japan, Korea and far east of the USSR; Western and central European Prov. (Portugal, Spain, France, Cornwall, Austria, etc.). The Sino-Malayen province is the most important, having more than $50 \%$ of the world reserves of tungsten and contributing about $30 \%$ of the concentrates produced worldwide ". Vd. Sobral e Fernando Sousa e Silva e Matias,Wolfram, technicalandeconomicaspects, Coimbra, F.C.T. 1980, p.16. According to Li and Wang, refers aswell towolframiticdeposits in Africa, Cuba and Canada, to those 6 metallogenic provinces, would add that of Brazil, John H. Kemler, The Struggle for wolfram in the Iberian Peninsula (Jun. 1942-Jun.944).Chicago, U.C., 1949, p. 5.

${ }^{3}$ In Trás-Os-Montes, Minho and Beiras - North and Center of Portugal and Galícia - Coruña, Santiago de Compostela, Orense.

4 "Na mina, o que maiscusta é sairdela", geology technician, working on land at the PanasqueiraMines, May 1998.

${ }^{5}$ With the First World War and the concomitant expansion of the armaments industry, there was an extraordinary increase in consumption and demand for tungsten, which led to the discovery of the great Chinese wolframite deposits. "In the late 1920s, tools with tungsten carbide started to be commercialized, at a time when by adding cobalt to the CW alloy, the problem of its fragility was solved ". Later, with the Spanish Civil War, World War II, the Korean War and with the recent development of the steel industry, increased consumption and demand for tungsten "... applications of tungsten are based on its properties of extreme hardness, resistance to use (tungsten carbide)and high temperatures... its behavior in relation to acids and aqua regia (it is not attacked, but soluble ...), as well as in the development of its applications in the nuclear and aerospace industry. The tungsten metal has the highest melting point of all metals ... it has good resistance to corrosion, good electrical and thermal conductivity and small heat expansion coefficient ". Vd. Fernando Sousa e Silva Sobral e Manuel João Senos Matias, Volframio, aspectos técnico-económicos, Coimbra, F. C.T., 1980, p. 1-3, $51-52$

${ }^{6}$ Fromthecollection of worksoncoalmining in thecontemporaryperiod, werefer, withdifferentperspectives of approach, Carlos Renato Carola, Dos Subterrtâneos da História: as trabalhadoras das minas de carvão de Santa Catarina (1937-1964). Florianópolis Univers. Federal de Santa Catarina, 1997. (policopiado); SuzyPasleau, La perception de la vieactive: d'une ètapedansleprogrès social a la mesure d'unfacteur de production, Seraing (XIX-XX siècles). Univers. de Liège, 1997, (policopiado); I. V. da Rocha, 0 carvão numa economia nacional: 0 caso das Minas do Pejão, Porto, Fac. de Letras, 1997 (policopiado).

${ }^{7}$ Graça Capinha, Tecendo e distorcendo o colonialismo da linguagem ... and Maria Irene Ramalho, A Poesia e Nós "Revista Critica de Ciências Sociais", Coimbra, n 47, Fev. 1997, p. 65-72 e p.5-21.

${ }^{8}$ In technical terminology, there are two different ways of calling the metal that is extracted from the wolframite ore: wolfram, designation currently given that ore, and tungsten. This last word derives from Swedish, from the association of the terms tung and sten,"which mean heavy stone, direct reference to the high density of the metal - 19.3; the word volframio is from the German, from the association of 'olf' and 'rahm', which mean foam or wolf drool, allusion to the fact that the tungsten 'devour' the tin (cassiterite) in melting beds, certainly and due to its high melting point $-3.419^{\circ} \mathrm{C}\left(6.170^{\circ} \mathrm{F}\right.$.). In Portugal, the wolfram is already mentioned in the Catalog of the Portuguese Industrial Exhibition of 1888, marking its good price in the market, although a few years ago it was considered as worthless slag and was thrown to rubble in the tin mines; at that time its application was on an increasing scale in the iron and steel industry, with recent discoveries of new applications... The presence of tungsten in the districts of Castelo Branco, Guarda, Viseu, Porto and Bragança was mentioned. " Fernando Sousa e Silva and Manuel João Senos Matias, "Volfrâmio, aspectos técnico-económicos", Coimbra, F. C. T., 1980.

${ }^{9}$ Portugal, the largest European producer of tungsten, reached 100,000 miners at the time of World War II, while in Galicia, 10,000 people wereregisteredtoworkatthetungsten, according respectively in an interview with eng. M.C. (Jun.1998), and Santiago Rodriquez, Dir. Realiz., A Fevre do wolfram, Santiago Rodriguez, 1995, 58m.

${ }^{10}$ Cotelo Neiva, Jazigos de cassiterite e volframite, Porto, Faculdade de Ciências, Tomo XXV, 1944.

${ }^{11}$ In 1943, the production of wolframite concentrates from Galicia would have reached 3000 tons, from a global of 4000 tons in Spain, according to official data. Respecting the Portuguese production, 
should be around 12 tons in 1985, was brought to 500 tons in 1906 and 1000 tons in 1910. By 1917, it has raised to 1500. Down graded below 1000 tons till 1935, and with the rearmament (1935-1938), it grows again, passing in 1938 the 2,810 ton. In 1941, 1942, 1943, the production exceeded 5,000 ton / year. In 1945 and 1946, the production was negligible, given to the legal embargo of Jun1944. From 1947 to 1950, the national production reached around 2,500 tones; in 1951 with Korean war, it raised up to 4700 , and in 1952, 4900tons. It remained above 4,000 ton/year until 1958, but that year it was 1,670 ton, due to the deep crisis and sharp drop in prices on the world market. In 1963, it was aimed the lowest value since 1917, with 1330 tons.

${ }^{12}$ The sociolect is formed by common words to a certain area or group of people, a kind of slang manufactured and not heard outside that region or social group.In formal terms, sociolect is, in the list of important terms of language in social contexts. It is a type of dialect that constitutes with sociotechnical varieties, ethnic and gender, the non-standard dialect, for example, with the regional dialect and others, of the diversity that characterizes the dialect reality. (Oswald Ducrot; TzvetanTodorov, Dictionnaireencyclopediquedessciencesdulangage, Paris, Ed. duSeuil, 1972; Mario Vilela, Linguagem e Ideologia, "Alma Nacional, Revista Republicana", Livraria Civilização, 1977; Heinz Kroll, O Eufemismo e o Disfemismo no português Moderno, Lisboa, ICALP, 1984).

${ }^{13 " T o}$ articulate means to establish the necessary mediations to affirm what links what seems 'naturally' separate, but also to create the conditions for divisions, separations and distinctions to be established through non-coercive and non-disqualifying practices fromothers. In this sense, the articulated testimony embodies the cosmopolitical relationship that Isabelle Stengers talks about." João Arriscado Nunes, "Para além das 'duas culturas': tecnociencias, tecnoculturas e teoria critica", Revista Critica de Ciencias Sociais, 52/53 (Coimbra, Nov.98/Fev.99), 5-50.

${ }^{14}$ Vinicius Morais, O Haver, mentionedby Carlos Guilherme Mota, Em busca de uma memória comum". RevistaCrítica de CiênciasSociais 32 (Coimbra, Jun. 1991) 35-55.

${ }^{15}$ It should be noted that equivalence in terms of written language is not verified in terms of phonetics and specific sonority of the spoken languages; in this regard, it may be considered that although oral speech may be a marker of social distinctions, the writing is the language of social selection, of power.

${ }^{16}$ despite its problematization, made in the preface of $2^{\text {nd }}$ edition (1944) of the novel Volfrâmio by Aquilino Ribeiro,novelist with "a more complex and pertinent view of the current social realities, their processes of effabulation and writing". Joel Serrão, "A novelística social da década de 40 - esboço de problematização" (The social novelistics of the 1940s -sketching of problematization), Colóquio Letras (Sept. 1972) 27.

${ }^{17}$ Today, it is for sureat any historical analysis, the economic and financial consequences of the war that wolfram, as a factor of national prosperity, acquires a prominent place, "The main consequence of the great increase in quantities and prices in the market for tungsten ore was the existence of positive balances in the Portuguese trade balance in 1941, 1942 and 1943, an unique event since there are official published series of Portuguese foreign trade." Eugénia Mata and Nuno Valério, História Económica de Portugal: Uma perspectiva global, Lisboa, Presença, 1994, p. 194-195. Or, "In the middle of 1941, several factors combine to shake the policy decided at the beginning of the conflict ... Internally, everything is combined to change the economic stability and social peace ... The evolution of the Portuguese trade balance reflects the changes mentioned.Exports suffered a spectacular increase (259\%, in value, since 1938) surpassing, in 1941, imports for the first time. Its structure has changed significantly: in 1938, the main exports were wines and spirits (20\%) followed by wood and derivatives (19\%) and preserves (17\%); in 1941, the main export is wolfram (18\%, officially), followed by preserves $(17 \%)$ and wood and wood products $(15 \%)$. The destination of exports has also changed, with a decrease in the weight of England, France and Belgium, and an increase in Germany, Switzerland and the USA ". António Telo, Portugal na Segundo Guerra, Lisboa, Perspectivas e Realidades, 1987, p. 458- 459.

${ }^{18}$ Fernando Namora, Minas de S.Francisco, 1946.

${ }^{19}$ Ibidem.

${ }^{20}$ Seetextspresented to conferencesandcongressesheld in Portugal, years 1997 and 1998: Do lado Sombra de lua: sobre a mulher no Portugal Volframizado (1938-1944); Dialecto e gíria de um 'negócio da china': O volfrâmio, semióforo de mercado em Portugal?; Minas, Trabalho de terreno e laboratórios: Emergência de redes sociotécnicas (Portugal anos 1930-60) (Fromthedarkside of themoon:aboutwomen in wolframized Portugal (1938-1944); 'china'sbusiness' dialectand slang: Wolfram, amarket'ssemiophore in Portugal?; Mines, fieldworkandlaboratories: Sociotechnical network emergency) . 
${ }^{21}$ By the way, the mining exploitation in Portugal, as in other semi-periphery and periphery countries, was since ever dependent on the techniques and technologies of countries of the "center".

${ }^{22}$ Not having found, in the field work and / or documentary research, no clue to the origin of this name thanks to Emmanuel and Gilda Santos, specialists in linguistics and literature, the following hypothesis "way found by workers to" translate "the word schon (= bonito) from German.It was certainly with this exclamation that the Germans received the special stones.",Correspondência, 1998.

${ }^{23}$ Fieldwork, Panasqueira, June 1998. Informants, medium technicians of design, geology and topography.

${ }^{24}$ P.e Manuel Vaz Leal, As Minas da Panasqueira: Vida e Historic, Lisboa, Portugália Editora, 1945, p. 74 - 78.

${ }^{25}$ Galician tungsten mines were spread over different areas of Coruña, Santiago de Compostela, Orense, Pontevedra, namely in Barbanza, Santa Comba, San Fins de Noia, A Penouta, Silleda, Casaio, Monte Neme, Arteixo.

26 José Jorge Álvares Pereira,Riquezas mineralógicas de Barroso e sua história(Barroso'smineralogicalrichesanditshistory), Montalegre, Edição da Camara, 1984, p. 25-36.

${ }^{27}$ Gilles Deleuze, O Fio de Ariana, Lisboa, Ed. Vega, 1996, p. 98.

${ }^{28}$ The sinusoidal line of totalization of historical experience in the systemic creationof Abel Salazar's history. See "Da disfunção da polémica àcomplementaridade..."("From the dysfunction of the controversy to the complementarity ...")

${ }^{29}$ Interview by G.S. to F.M. dos S., former mining worker. Rio de Janeiro 1998.

${ }^{30}$ Title of videographic documentary referenced in the next note.

${ }^{31}$ Interviewed in thedocumentary X.L. Santiago Rodriguez (Dir, e Realiz.), A Fevre do Wolfram. Edic. Xoan Garcia, 1995 (video VHS, 58)of which the director kindly

${ }^{32}$ Interview with X. F.T., former worker in the wolfram's mines of Monte Neme, Galicia. Monte Neme, March 1998.

${ }^{33}$ J.A. Nunes, cit. art.

${ }^{34}$ See for the history of this controversy about the relationship between Portuguese and Galician, the article by Elias José Torres Feijó, "Cultura portuguesa e legitimação do sistemagaleguista: historiadores e filólogos (1880-1891)" LerHistória 36 1999) 273-318.

providedus with a copy, namely to integrate in the audiovisual archiveMinas: Paisagens, Ruinas, Miragens (Mines: Landscapes, Ruins, Mirages) that we produced over the course of 4 years of field work, in the regions of wolfram.

\section{AUTHOR'S BIOGRAPHIES}

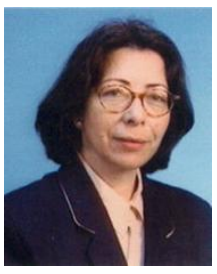

Maria Otilia Pereira Lage (Porto, Portugal), master anddoctor in ModernandContemporaryHistory (Univ. Minho), post-doctorate in HistoricalandSocial Studies (Univ. Coimbra), integratedresearcherat CITCEM (Univ.Porto), member of theBoard CEPHIS andthe Editorial Board of Review CEPHIS, member of Portuguese andforeign Professional and Scientific Associations, author of dozens of books, essays, articles, conferencesandcommunications.

Citation: Maria Otília Pereira Lage. "In the memories of Wolfram - a Portuguese-Galician Sociolect" International Journal of Humanities Social Sciences and Education (IJHSSE), vol 7, no. 7, 2020, pp. 124-134. doi: http://dx.doi.org/10.20431/2349-0381.0707015.

Copyright: (c) 2020 Authors. This is an open-access article distributed under the terms of the Creative Commons Attribution License, which permits unrestricted use, distribution, and reproduction in any medium, provided the original author and source are credited. 